\title{
Antioxidant and antibacterial activities of Turkish endemic Sideritis extracts
}

\author{
By Gülcan Özkan ${ }^{1}$, Osman Sagdiç ${ }^{2, *}$, Musa Özcan ${ }^{3}$, Hasan Özçelik ${ }^{4}$ and Ahmet Ünver ${ }^{3}$
}

\author{
${ }^{1}$ Department of Food Engineering,Faculty of Agricultural, Suleyman Demirel University, \\ 32260 Isparta-Turkey \\ 2 Department of Food Engineering, Faculty of Engineering, Erciyes University, 32260 Kayseri \\ ${ }^{3}$ Department of Food Engineering, Faculty of Agricultural, Selcuk University, 42031 Konya-Turkey \\ ${ }_{4}$ Department of Biology, Faculty of Science and Letters, Suleyman Demirel University, \\ 32260 Isparta-Turkey \\ * Corresponding author. Fax: +90-352-4375784; E-mail address: osagdic@erciyes.edu.tr
}

\section{RESUMEN}

Actividades antibacteriana y antioxidante de extractos de especies endémicas turcas de Sideritis.

Las especies de Sideritis se usan tradicionalmente para la elaboración del té, como flavorizantes y con fines médicos en Turquía. En este estudio, se han determinado las actividades antimicrobiana y antioxidante de extractos de especies endémicas de la Familia Lamiaceae, como son Sideritis condensata Boiss. \& Heldr. (SC) y Sideritis erythrantha var. erythrantha Boiss. \& Heldr. (SE). La actividad antibacteriana fue determinada mediante el método de difusión en agar con 15 especies de bacterias: Aeromonas hydrophila, Bacillus cereus, Enterobacter aerogenes, Enterococcus faecalis, Escherichia coli, Escherichia coli 0157:H7, Klebsiella pneumoniae, Mycobacterium smegmatis, Proteus vulgaris, Pseudomonas aeruginosa, Pseudomonas fluorescens, Salmonella enteritidis, Salmonella typhimurium, Staphylococcus aureus y Yersinia enterocolitica. Se consideraron diferencias estadísticamente significativas cuando $p<0,05$. El extracto de SC tuvo mayor actividad antimicrobiana que el extracto de SE. La bacteria más sensible fue $P$. aeruginosa, mientras que las más resistentes fueron $E$. faecalis para el extracto de SC, y E. faecalis y $S$. aureus para el extracto de SE. También se determinó en los extractos el contenido de polifenoles, la capacidad de secuestrar radicales libres mediante el método del 1,1-difenil-2-picrilhidrazilo (DPPH), y la capacidad antioxidante mediante el método de formación del complejo fosfomolibdeno. Los compuestos fenólicos totales fueron $247,62 \pm 1,91 \mathrm{mg}$ de equivalentes de ácido gálico $(\mathrm{GAE}) / \mathrm{g}$ de extracto seco en SC, y $217,61 \pm 0,95 \mathrm{mg} \mathrm{GAE} / \mathrm{g}$ de extracto seco en SE. A la concentración de 100 ppm, se observó

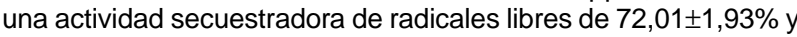
$71,48 \pm 1,95 \%$ para los extractos de SC y SE, respectivamente. La actividad antioxidante mediante el método del fosfomolibdeno fue de $279,37 \pm 3,61$ y $146,11 \pm 3,11 \mathrm{mg} / \mathrm{g}$ de extracto seco de SC y SE, respectivamente.

PALABRAS-CLAVE: Actividad antimicrobiana - Actividad antiradicales - Antioxidante - Extractos de Sideritis

\section{SUMMARY}

Antioxidant and antibacterial activities of turkish endemic Sideritis extracts.

Sideritis species are traditionally used as teas, flavoring agents and for medicinal purposes in Turkey. In this study, the antioxidant and antimicrobial activities of Sideritis condensata Boiss. \& Heldr. (SC) and Sideritis eryhrantha var. erythrantha Boiss. \& Heldr. (SE) endemic species' extracts of Lamiaceae were determined. These extracts were investigated for antibacterial activity by using the agar diffusion method against 15 species of bacteria: Aeromonas hydrophila, Bacillus cereus, Enterobacter aerogenes, Enterococcus faecalis, Escherichia coli, Escherichia coli 0157:H7, Klebsiella pneumoniae, Mycobacterium smegmatis, Proteus vulgaris, Pseudomonas aeruginosa, Pseudomonas fluorescens, Salmonella enteritidis, Salmonella typhimurium, Staphylococcus aureus and Yersinia enterocolitica. Statistical differences within bacteria were significant at $p<0.05$. $\mathrm{SC}$ extract was more effective than the other. At all concentrations, although the most sensitive bacteria was $P$ aeruginosa, the most resistant bacteria were $E$. faecalis for SC extract and E. faecalis, S. aureus for SE extract. Total phenolics, radical scavenging activity by 1,1-diphenyl-2-picrylhydrazyl (DPPH) method and the antioxidant capacities by the formation of phosphomolybdenum complex method of the extracts were determined. The total phenolics were found as $247.62 \pm 1.91 \mathrm{mg}$ gallic acid equivalent (GAE)/g in SC extract and $217.61 \pm 0.95 \mathrm{mg}$ $\mathrm{GAE} / \mathrm{g}$ in SE extract of dried weight. At $100 \mathrm{ppm}$ concentration, the free radical scavenging activities of SC and SE extracts were found as $72.01 \pm 1.93$ and $71.48 \pm 1.95 \%$, respectively. The antioxidant activities by phosphomolybdenum method of SC and SE extracts were $279.37 \pm 3.61$ and $146.11 \pm 3.11 \mathrm{mg} / \mathrm{g}$ dried extract.

KEY-WORDS: Antibacterial activity - Antioxidant - Antiradical activity - Sideritis extracts

\section{INTRODUCTION}

Sideritis condensata Boiss. \& Heldr. (SC) and Sideritis eryhrantha Boiss. \& Heldr var. erythrantha (SE) taxa, also known as mountain tea, are perennial herbs that grow in the mountainous regions between southern Europe and the eastern Mediterranean. About 100 species of Sideritis have been distinguished in the world. In Turkey, the herbs of most Sideritis species (Özhatay, et al., 1998), including 24 endemics (and two endemic subspecies) were found to be collected at least locally (Özçelik, 2000).

The Genus Sideritis contains antimicrobial and antioxidant polyphenolics such as flavonoids (especially flavones and flavonol glycosides). The freeze-dried extract of Sideritis, before and after hydrolysis, were found to be rich in bound forms of phenolic compounds such as 5,8,3'-trihydroxy4'-methoxyflavone, 7-(6"'-O-acetylsophoroside) 
together with apigenin 7-(6"-p-coumaroylglucoside) and apigenin 7-(4"-p-coumaroylglucoside) (Palomino et al., 1996; Venturella et al., 1995; GomezSerranillos et al., 1998).

Mountain tea contains a fragrant oil and other aromatic substances that are widely used as tonics, carminatives, diuretics and digestives, and in the treatment of colds (Baytop, 1984; Koedam, 1986; Yesilada and Ezer, 1989; Ezer et al., 1991). Some studies on the essential oil composition of mountain tea have been carried out and results have been shown in literature (Kirimer et al., 1996; Baser et al., 1997; Özcan et al., 2001). In addition to this, the tea is pleasantly aromatic and the essential oils and extracts of this aromatic herb have been shown to have potent antioxidant activity in lipid substrates (Lemberkovics et al., 1998). Several active ingredients of Sideritis have also been synthesized for their antimicrobial properties. The in vitro antimicrobial activity of the essential oils against six bacteria and three fungi has also been reported (Aligiannis et al., 2001). Sideritis medicinal decoctions have been shown to exert their anti-inflammatory effects through two different mechanisms. Sideritis also contains diterpenoids, especially andalusol previously described (Navarro et al., 1996).

Although, as antimicrobial compounds, many spicies and their derivatives have been studied in detail against important human pathogenic bacteria (Sagdiç et al., 2002; Sagdiç and Özcan, 2003; Özkan et al., 2003), there are no research reports on the antimicrobial and antioxidant effect of Sideritis condensata and $S$. eryhrantha var. erythrantha extracts. In this study, it was aimed to determine the antioxidant and antimicrobial activity of some endemic Sideritis extracts.

\section{MATERIALS AND METHODS}

\subsection{Plant materials}

The aerial parts of mountain teas of Sideritis condensata (SC) and S. eryhrantha var. erythrantha (SE), endemics for Turkey, were collected during the flowering stage from Isparta, Sütçüler city, the southwestern part of Turkey in August, 2002 at altitudes of $1400-1600 \mathrm{~m}$. The plants were identified by Dr. H. Özçelik, Director of the Herbarium Section, Isparta. Voucher specimens were deposited at the Herbarium of the University of Süleyman Demirel, Isparta, Turkey.

\subsection{Preparation of the herb extracts}

Dried herb at room temperature was ground to fine powder with a grinder. Then the powdered plant material $(10 \mathrm{~g})$ was extracted in a Soxhlet extractor with $100 \mathrm{ml}$ methanol $\left(60{ }^{\circ} \mathrm{C}\right.$ for $\left.6 \mathrm{~h}\right)$ to obtain an extract. The sample was then filtered through Whatman No 1 paper in a Buchner funnel and the filtered solution was evaporated at reduced pressure (Rotavator, $\mathrm{T}<40{ }^{\circ} \mathrm{C}$ ) to obtain crude extract. They were kept in a desiccator until use (Gu and Weng, 2001). The extractions were performed in duplicate.

\subsection{Determination of total phenolics}

The concentration of phenolic compounds in the extracts was determined by the Folin-Ciocalteu colorimetric method (Singleton and Rossi, 1965). Estimations were carried out in triplicate and calculated from a calibration curve obtained with gallic acid. Total phenolics were expressed as gallic acid equivalents (mg GAE/g extract).

\subsection{Antiradical activity determination}

A $1.0 \mathrm{ml}$ methanolic solution of the extracts and butylated hydroxytoluen (BHT) at $100 \mathrm{ppm}$ (methanol for the control) was placed in a test tube, and $2.0 \mathrm{ml}$ of a a, a-diphenyl-ß- picrylhydrazyl (DPPH) methanolic solution (10 ppm) was added. The absorbance was measured at $517 \mathrm{~nm}$ after 5 min of reaction. The percentage of DPPH decoloration of the samples was calculated according to the formula (Lee et al., 1998):

Antiradical activity $=100 \times(1$-absorbance of sample/absorbance of control)

\subsection{Evaluation of antioxidant activity}

The antioxidant activity of the samples was evaluated by the phosphomolybdenum method according to the procedure of Prieto et al. (1999). An aliquot of $0.4 \mathrm{ml}$ of sample solution $(100 \mathrm{ppm}$ in methanol) was combined in a vial with $4 \mathrm{ml}$ of reagent solution ( $0.6 \mathrm{M}$ sulfuric acid, $28 \mathrm{mM}$ sodium phosphate and $4 \mathrm{mM}$ ammonium molybdate). The vials were capped and incubated in a water bath at $95{ }^{\circ} \mathrm{C}$ for $90 \mathrm{~min}$. After the samples had cooled to room temperature, the absorbance of the mixture was measured at $695 \mathrm{~nm}$ against a blank. The antioxidant activity was expressed relative to that of ascorbic acid.

\subsection{Bacterial cultures}

The fifteen bacteria were used as test organisms: Aeromonas hydrophila ATCC 7965, Bacillus cereus FMC 19, Enterobacter aerogenes CCM 2531, Enterococcus faecalis ATCC 15753, Escherichia coli DM, Escherichia coli 0157:H7 KUEN 1461, Klebsiella pneumoniae FMC 5, Mycobacterium smegmatis RUT, Proteus vulgaris FMC 1, Pseudomonas aeruginosa ATCC 27853, Pseudomonas fluorescens 
EU, Salmonella enteritidis, Salmonella typhimurium, Staphylococcus aureus Cowan 1 and Yersinia enterocolitica EU. These bacteria were supplied by the Department of Biology, Sütçü Imam University, Kahramanmaras-Turkey.

\subsection{Determination of antibacterial effect}

P. vulgaris, P. aeruginosa, P. fluorescens, and $Y$. enterocolitica were grown in nutrient broth (Acumedia Manufacturers, Inc., Maryland) at $25{ }^{\circ} \mathrm{C}$ for $22 \mathrm{~h}$. The other bacteria were grown in the same medium at $35{ }^{\circ} \mathrm{C}$ for $22 \mathrm{~h}$ (Ilçim et al., 1998). All test bacteria in nutrient broth were enumerated by using the serial dilution method. Final cell concentrations were $10^{6}-10^{7} \mathrm{cfu} / \mathrm{ml} .250 \mu$ of each bacteria was added into a flask containing $25 \mathrm{ml}$ sterile nutrient agar at $45^{\circ} \mathrm{C}$ and poured into Petri dishes ( $8 \mathrm{~cm}$ diameter). Then the agar was allowed to solidify at $4{ }^{\circ} \mathrm{C}$ for $1 \mathrm{~h}$. The agar diffusion method was used to detect the antibacterial activity of the extracts. Four equidistant holes were made in the agar using sterile cork borers $(\varnothing=4 \mathrm{~mm}) .50 \mu \mathrm{l}$ of 1 , $2.5,5$, and $10 \%$ volume of methanolic (MerckDarmstadt, Germany) extract solutions was added to the holes using a pipettor and absolute methanol was used as control. The $P$. vulgaris, $P$. aeruginosa, $P$. fluorescens, and $Y$. enterocolitica bacteria test plates were refrigerated at $8{ }^{\circ} \mathrm{C}$ for $1 \mathrm{~h}$ and then incubated at $25{ }^{\circ} \mathrm{C}$ for $18-24 \mathrm{~h}$ in the inverted position. The other bacteria were grown in the same media at $35{ }^{\circ} \mathrm{C}$ for $18-24 \mathrm{~h}$. At the end of the period, inhibition zones which formed on the medium were measured in millimetres $(\mathrm{mm})$. All the tests were performed in triplicate.

\subsection{Statistical analyses}

SPSS 10.0 was used to compare the data and all the tests were considered statistically significant at $\mathrm{p}<0.05$ (Özdamar, 1999).

\section{RESULTS AND DISCUSSION}

In this study, total yields (\%), total phenolics (mg GAE/g), antiradical activities (\%), antioxidant activities $(\mathrm{mg} / \mathrm{g})$ and antibacterial effects of two Sideritis extracts were determined. The percent yields of the extracts were determined as $4.77 \pm 0.93$ for SE and $6.47 \pm 0.95$ for SC.

The amounts of total phenolics extracted with methanol were determined as $217.61 \pm 0.95 \mathrm{mg}$ GAE/g in dried weight of SE extract and 247.62 \pm 1.91 $\mathrm{mg} \mathrm{GAE} / \mathrm{g}$ in SC extract. Statistically, differences between total phenolics of the two extracts were significant. SC extract had total phenolics higher than SE extract.
At $100 \mathrm{ppm}$ concentration, the free radical scavenging activity of SC and SE extracts were found as $72.01 \pm 1.93$ and $71.48 \pm 1.95 \%$, respectively. It was found that BHT (as control) antiradical activity was as $39.02 \pm 1.02 \%$ at the same concentration. Statistically no differences were found between the two extracts for antiradical activity. The activity of the extracts is attributed to their hydrogen donating ability (Shimada et al., 1992). It is well known that free radicals cause auto oxidation of unsaturated lipids in food (Kaur and Perkins, 1991). In comparison with $\mathrm{BHT}$, these data obtained reveal that the extracts are free radical inhibitors and primary antioxidants that react with the radicals. Koleva et al. (2003) found ranges from 90 to $94 \%$ for S. scardica, S. montana and S. syriaca methanolic extracts, respectively.

The antioxidant activities of SC and SE extracts showed $279.37 \pm 3.61$ and $146.11 \pm 3.11 \mathrm{mg} / \mathrm{g}$ dried extract (equivalent to ascorbic acid), respectively. Koleva et al. (2003) found that antioxidant activity ( $\beta$-carotene bleaching test method) of Sideritis scardica, S. montana and S. syriaca methanolic extracts changed from 48.2 to $72.5 \%$. Statistical differences between the two extracts were important for antioxidant activity analyses. The method is based on the reduction of Mo $(\mathrm{VI})$ to $\mathrm{Mo}(\mathrm{V})$ by the antioxidant compounds and the formation of a green Mo (V) complex with maximum absorption at $695 \mathrm{~nm}$ (Prieto et al., 1999). The reducing properties are generally associated with the presence of reductones and the antioxidant action of reductones is based on the breaking of the free radical chain by donating a hydrogen atom (Gordon, 1990; Pin-Der Duh, 1998). According to Jayaprakasha et al. (2003), the antioxidant activity of different extracts may depend on the presence of polyphenols which may act as reductones.

The effects of extracts at $10,5,2.5$ and $1 \%$ on the test bacteria are presented in Table I. Methanol (control) had no inhibitory effects on the fifteen bacteria tested, and the extracts at the lowest $(2.5$ and $1 \%$ ) concentrations were also the least effective. Statistical differences within bacteria were important. While, the SC extract at 10 and $5 \%$ concentration exhibited antibacterial effects against all the bacteria except $E$. faecalis, the SE extract at the same concentration exhibited antibacterial effects against all the bacteria except $S$. aureus and E. faecalis. SC extract was more effective than SE. At all concentrations, the most sensitive bacterium was $P$. aeruginosa, the most resistant bacteria were $E$. faecalis to SC extract and E. faecalis, S. aureus to SE extract. Similarly, Kiliç et al. (2003) reported that Sideritis athoa, Sideritis trojana, Sideritis dichotoma, Sideritis spilyea, and Sideritis argyrea essential oils were active against E. coli, S. aureus, P. aeruginosa, $K$. pneumoniae and E. faecalis. On the contrary, 
Table I

Antibacterial activity of two Sideritis extracts (inhibition zones, $\mathrm{mm}$ )

\begin{tabular}{lcccccccc}
\hline \multirow{2}{*}{ Bacteria } & \multicolumn{9}{c}{ SC extract } & \multicolumn{5}{c}{ SE extract } \\
\cline { 2 - 9 } & $\mathbf{1 0}$ & $\mathbf{5}$ & $\mathbf{2 . 5}$ & $\mathbf{1}$ & $\mathbf{1 0}$ & $\mathbf{5}$ & $\mathbf{2 . 5}$ & 1 \\
\hline A. hydrophila & $17 \pm 2.93$ & $13 \pm 2.12$ & $11 \pm 5.00$ & $7 \pm 2.14$ & $11 \pm 2.83$ & $8 \pm 2.42$ & $6 \pm 3.06$ & - \\
B. cereus & $15 \pm 1.86$ & $14 \pm 2.41$ & $8 \pm 2.14$ & $7 \pm 2.41$ & $12 \pm 1.77$ & $10 \pm 2.46$ & $9 \pm 3.04$ & - \\
E. aerogenes & $13 \pm 3.22$ & $8 \pm 1.88$ & $8 \pm 2.45$ & - & $9 \pm 1.78$ & $8 \pm 2.10$ & $7 \pm 2.15$ & - \\
E. faecalis & - & - & - & - & - & - & - & - \\
E. coli & $15 \pm 1.42$ & $13 \pm 3.11$ & $11 \pm 0.65$ & $7 \pm 2.56$ & $11 \pm 3.14$ & $8 \pm 1.29$ & $7 \pm 2.18$ & $6 \pm 2.77$ \\
E. coliO157:H7 & $13 \pm 1.21$ & $12 \pm 2.18$ & $10 \pm 0.41$ & $7 \pm 2.44$ & $8 \pm 2.48$ & $7 \pm 0.48$ & $7 \pm 2.21$ & - \\
K. pneumoniae & $12 \pm 0.99$ & $12 \pm 2.13$ & $10 \pm 0.76$ & $6 \pm 1.18$ & $12 \pm 100$ & $10 \pm 1.29$ & $7 \pm 0.45$ & - \\
M. smegmatis & $14 \pm 1.26$ & $12 \pm 2.13$ & $12 \pm 1.21$ & $7 \pm 1.74$ & $10 \pm 078$ & $8 \pm 2.35$ & $8 \pm 1.64$ & $6 \pm 2.41$ \\
P. vulgaris & $16 \pm 2.03$ & $9 \pm 1.16$ & $8 \pm 2.14$ & $6 \pm 2.85$ & $10 \pm 146$ & $8 \pm 2.11$ & $7 \pm 1.64$ & $6 \pm 2.63$ \\
P. aeruginosa & $17 \pm 2.00$ & $14 \pm 0.98$ & $12 \pm 1.89$ & $9 \pm 3.00$ & $19 \pm 148$ & $17 \pm 2.78$ & $11 \pm 3.01$ & $7 \pm 2.01$ \\
P. fluorescens & $14 \pm 3.01$ & $12 \pm 0.42$ & $9 \pm 0.78$ & $6 \pm 3.47$ & $16 \pm 1.19$ & $12 \pm 2.99$ & $10 \pm 3.18$ & - \\
S. enteritidis & $17 \pm 1.78$ & $13 \pm 2.99$ & $10 \pm 1.32$ & $6 \pm 0.98$ & $8 \pm 0.74$ & $8 \pm 1.99$ & $7 \pm 2.58$ & - \\
S. typhimurium & $14 \pm 1.66$ & $12 \pm 2.16$ & $11 \pm 1.56$ & $6 \pm 1.19$ & $13 \pm 1.12$ & $12 \pm 0.96$ & $8 \pm 2.75$ & - \\
S. aureus & $7 \pm 2.46$ & $6 \pm 3.03$ & $6 \pm 0.87$ & - & - & - & - & - \\
Y. enterocolitica & $8 \pm 2.11$ & $7 \pm 2.41$ & - & - & $7 \pm 1.45$ & - & - & - \\
\hline
\end{tabular}

\footnotetext{
a Values expressed are meanstandard deviation of three experiments ( $p$ )

- : not detected
}

Hernandez-Perez and Rabanal Gallego (2002 a,b) found no relevant antimicrobial activity of the antimicrobial activities of crude ethanol extracts of Sideritis lotsyi var. mascaensis and Sideritis canariensis var. pannosa against the microorganisms tested such as $S$. aureus, $B$. cereus var. mycoides, $K$. pneumoniae, P. aeruginosa and E. coli.

Generally, the extent of the antioxidant and antibacterial effects of the genus Sideritis contained in the extracts could be attributed to their phenolic composition such as flavonoids (Palomino et al., 1996; Navarro et al., 1996; Venturella et al., 1995).

Our results suggest that the Sideritis extracts drunk as tea in Turkey may be used as antibacterial agents to prevent the deterioration of stored foods by bacteria, if any organoleptic effects are acceptable. In addition, Sideritis extracts (and/or their components) may serve as natural antioxidative additives which do not produce toxic effects or impart unpleasant taste/color to foods. After these screening experiments, further work will be performed to describe the antioxidative and antimicrobial activities in more detail.

\section{REFERENCES}

Aligiannis, N., Kalpoutzakis, E., Chinou, I.B., Mitakou, S., Gikas, E., Tsarbopoulos, A. (2001). Composition and antimicrobial activity of the essential oils of five taxa of Sideritis from Greece. J. Agric. Food Chem., 49 (2), 811-815.
Baser, K.H.C., Kirimer, N., Tümen, G. (1997). The essential oil of Sideritis scardica Griseb. subsp. scardica. J. of Essential Oil Research, 9, 205-207.

Baytop, T. (1984). Therapy with Medicinal Plants in Turkey (Post and Present). Istanbul Univ. Publ. No.3255, Istanbul, Turkey.

Ezer, N., Sezik, E., Erol, K., Özdemir, M. (1991). The antispasmodic activity of some Sideritis species. In: K.H.C.Baser (ed.), Proc. $9^{\text {th }}$ Symp. On Plant Drugs, 16-19 May (pp.88-93). Turkey: Eskisehir (in Turkish).

Gomez-Serranillos, P., Carretero, E., Slowing, K., Palomino, O. M., Villarrubia A. I., Villar, A. (1998). HPLC Quantitative Analysis of Diterpenoids in Sideritis (Labiatae) Species. Phytotherapy Research, 12, 101-103.

Gordon, M.F. (1990). The mechanism of antioxidant action in vitro. In: Hudson B.J.F. (ed), Food antioxidants London: Elsevier Applied Science pp. 1-18.

Gu, L., Weng, X. (2001). Antioxidant activity and components of Salvia plebeia R. Br.- a chinese herb. Food Chem., 73, 299-305.

Hernandez-Perez, M., Rabanal Gallego, R.M. (2002a). Analgesic and Antiinflammatory Properties of Sideritis lotsyi var. mascaensis. Phtotherapy Research, 16, 264-266.

Hernandez-Perez, M., Rabanal Gallego, R.M. (2002b). Evaluation of the antinflammatory and analgesic activity of Sideritis canariensis var. pannosa in mice. $J$. of Ethnopharmacology, 81, 43-/47.

Ilçim, A., Digrak, M., Bagci, E. (1998). The investigation of antimicrobial effect of some plant extract. Turkish $\mathrm{J}$. of Biol., 22,119-125.

Jayaprakasha, G.K., Selvi, T., Sakariah, K.K. (2003). Antibacterial and antioxidant activities of grape (Vitis vinifera) seed extracts. Food Res. Int., 36, 117-122.

Kaur, H., Perkins, J. (1991). The free radical chemistry of food additives. In O. I. Aruoma \& Halliwell (Eds.), Free 
radicals and food additives (pp. 17-35). London: Taylor and Francis Ltd.

Kiliç, T., Yildiz, Y.K., A.C., Goren, G., Tumen, Topcu, G. (2003). 1 -4 Phytochemical analysis of some Sideritis species of Turkey. Chemistry of Natural Compounds, 39(5), 453-456.

Kirimer, N., Kürkçüoglu, M., Özek, T., Baser, K.H.C. (1996). Composition of the essential oil of Sideritis condensate Boiss. Et Heldr. Flavour and Fragrance Journal, 11, 315-320.

Koedam, A. (1986). Volatile oil composition of Greek mountain tea (Sideritis spp.). J. Sci. Food Agric., 36, 681-684.

Koleva, I.I., Linssen, J.P.H., van Beek, T.A. Evstatieva, L.N., Kortenska, V., Handjieva, N. (2003). Antioxidant activity screening of extracts from Sideritis species (Labiatae) grown in Bulgaria. J. Sci. Food Agric., 83, 809-819.

Lee, S.K., Mbwambo, Z.H., Chung, H.S., Luyengi, L., Games, E.J.C., Mehta, R.G., Kinghorn, A.D., Pezzuto, J.M. (1998). Evaluation of the antioxidant potential of natural products. Combin. Chem. High Throughput Screen., 1, 35-46.

Lemberkovics, E., Kery, A., Marczal, G., Simandi, B., Szoke, E. (1998). Phytochemical evaluation of essential oils, medicinal plants and their preparations. Acta Pharm Hung., 68 (3), 9-141.

Navarro, A., Godoy, A. J., de las Heras, B., Villar, A. (1996). An approach to the mechanism of action of an anti-inflammatory diterpenoid from Sideritis foetens. Prostagland. leukotri. essent. Fatty Acids, 55, 95-103.

Özcan, M., Chalchat, J.C., Akgül, A. (2001). Essential oil composition of Turkish mountain tea (Sideritis spp.). Food Chem., 75, 459-463.

Özçelik, H. (2000). Studies on protections of endemic and rare plants of lakes region. Bulletin of Pure and Applied Sciences, 19B(2), 93-116.

Özdamar, K. (1999). SPPS ile Bioistatistik. ETAM A.S. Matbaa Tesisleri, Yayin No: 3, 454 s., Eskisehir.

Özhatay, N., Koyuncu, M., Atay, S., Byfield, A. (1998). The trade in wild medicinal plants in Turkey. In 'Medicinal plant trade in Europe: conservation and supply', eds TRAFFIC EUROPE, pp. 5-18. Proceeding of the First International Symposium on the Conservation of
Medicinal Plants in Trade in Europe. TRAFFIC Europe, Brussels.

Özkan, G., Sagdiç, O., Özcan, M. (2003). Inhibition on pathogenic bacteria by essential oils at different concentrations. Food Sci. Technol. Int., 9(2), 85-88.

Palomino, O.M., Sollhuber, M., Carretero, E., Villar, A. (1996). Isoscutellarein 7-glucosyl(1--2) xyloside from sixteen species of Sideritis. Phytochemistry, 42 (1), 2-101.

Pin-Der Duh, X. (1998). Antioxidant activity of Budroock (Arctium lapp Linn.): its scavenging effect on free radical and active oxygen. J. Am. Oil Chem. Soc., 75, 455-461.

Prieto, P., Pineda, M., Aguilar, M. (1999). Spectrophotometric quantitation of antioxidant capacity through the formation of a Phosphomolybdenum Complex: Specific application to the determination of vitamin E. Anal. Biochem., 269, 337-341.

Sagdiç, O., Kusçu, A., Özcan, M., Özçelik, S. (2002). Effects of Turkish spice extracts at various concentrations on the growth of Escherichia coli O157:H7. Food Microbiol., 19, 80-473.

Sagdiç, O., Özcan, M. (2003). Antibacterial activity of Turkish spice hydrosols. Food Control, 14, 141-143.

Shimada, K. K., Fujikawa, K. Y., Nakamura, T. (1992). Antioxidative properties of xanthan on autooxidation of soybean oil in cyclodextrin. J.Agric. Food Chem., 40, 945-948.

Singleton, V.L., Rossi, J.R. (1965). Colorimetry of total phenolics with Phosphomolibdic-phosphothungstic acid. Am.J Enol. Vitic., 16, 144-158.

Venturella, P., Bellino A., Marino, M.L. (1995). Three acylated flavone glycosides from Sideritis syriaca. Phytochemistry, 38 (2), 527-30.

Yesilada, E., Ezer, N. (1989). The anti-inflammatory activity of some Sideritis species growing in Turkey. Int. J. Crude Drug Research, 27, 38-40. 